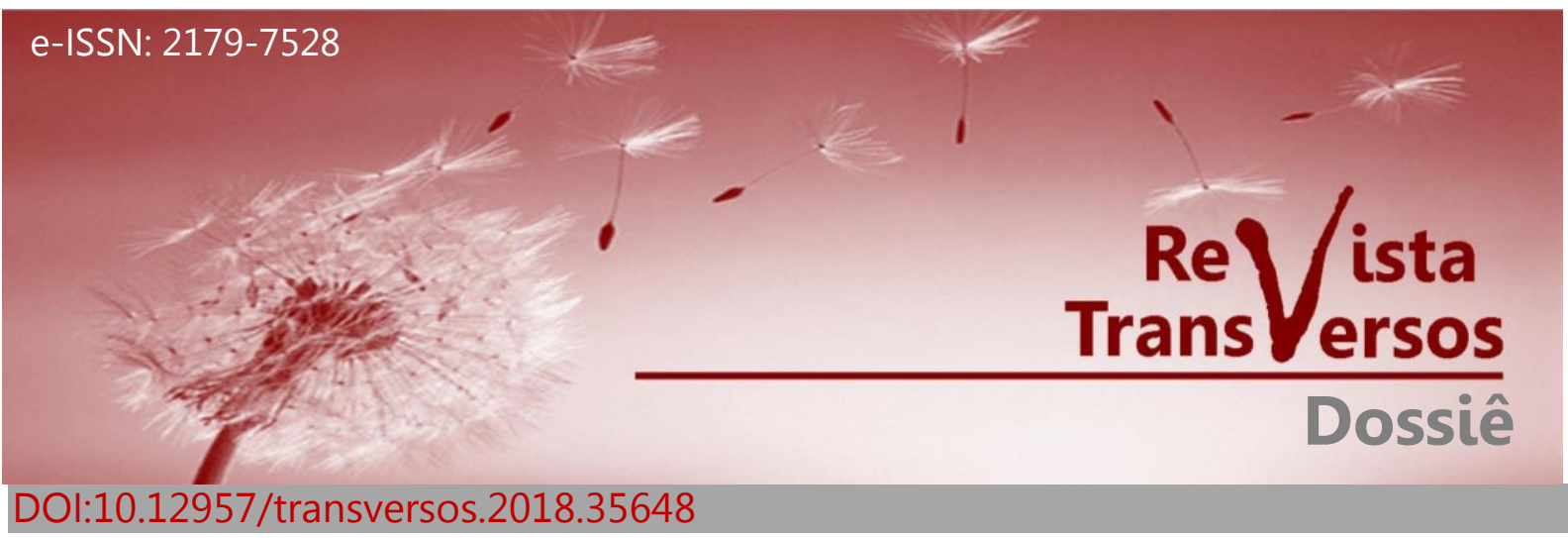

\title{
O COMBATE À DOENÇA DO SONO NAS COLÔNIAS PORTUGUESAS NA ÁFRICA: MEDICINA SOB O SIGNO DO RACISMO E DO DARWINISMO SOCIAL (1901-1932) THE COMBAT TO SLEEPING SICKNESS IN PORTUGUESE COLONIES IN AFRICA:EDICINE UNDER THE SIGN OF RACISM AND SOCIAL DARWINISM (1901-1932)
}

Ewerton Luiz Figueiredo Moura da Silva Faculdade de Medicina da Universidade de São Paulo ewertonfigueiredo@usp.br

\section{RESUMO}

A doença do sono ou tripanossomíase humana africana teve sua importância na agenda imperialista europeia, pois foi considerada um importante obstáculo para a formação de seus impérios coloniais na África. Neste cenário, as autoridades portuguesas, desejosas em defender as colônias do país frente à concorrência europeia e em promover a ação "civilizadora" de Portugal, enviaram missões de estudo e de combate das chamadas doenças tropicais às possessões ultramarinas do país. As estratégias de domínio colonial não passaram somente pelo controle das doenças presentes nas colônias, mas também no esforço para combater os saberes e as práticas associados à doença e à cura das sociedades africanas, tratadas na época como racialmente inferiores pelos poderes europeus.

Palavras-chaves:doença do sono; Portugal; darwinismo social; medicina tropical.

\begin{abstract}
Africansleepingsicknessorhumantrypanosomiasisp layedanimportant role in theEuropeanimperialist agenda, as it wasconsidered a major obstacletotheformationof its empires in Africa. In thisscenario, thePortugueseauthorities, anxioustodefendthecountry'scoloniesagainstEuro peancompetitionandtopromotethe "civilizing" actionof

sentmissionstostudyandcombattheso-called

tropical

diseasestothecountry'soverseaspossessions.

Colonial

dominationstrategiesdidnotonlycontrolthedisease spresent in thecolonies, butalsotheefforttocombattheknowledgeandhealin gpracticesofAfricansocieties, treatedatthe time as racially inferior bytheEuropeanpowers.
\end{abstract}

Keywords:Sleepingsickness; Portugal; social Darwinism; tropical medicine.

\section{Introdução}

Em 1898 o médico britânico Patrick Mansondefiniu como doenças tropicais um conjunto de enfermidades parasitárias provocadas por microrganismos que

Artigo recebido em 01 de julho de 2018 e aprovado em 14 de agosto de 2018. 
necessitam de determinadas condições climáticas, em sua fase extracorporal, para a sua sobrevivência, ou ainda, dependiam da ação de hospedeiros intermediários queagiam como vetores para a sua propagação. Estas condições estariam presentes em áreas de clima tropical (MANSON, 1898: p.17-24). No entanto, a noçãode trópicosnão deve ser compreendida apenas como um espaço físico e geográfico, mas sim encarada em sua carga conceitual, um processo de alteridade onde os europeus caracterizaram regiões política e culturalmente diferentes da Europa, bem como um ambiente distinto das áreas de clima temperado (ARNOLD, 1996: p.6).

A chamada Medicina Tropical desenvolveu-se como especialidade médica na virada do século XIX para o século XX, em um contexto histórico marcado pelo advento da microbiologia e da agenda imperialista europeia através da intensificação de seu domínio sobre o continente africano, partilhado quase que totalmente em colônias controladas por sete países ocidentais europeus. Portugal, antigo país colonizador, manteve seu quinhão nesta partilha comAngola, Moçambique,Guiné, Cabo Verde e São Tomé e Príncipe. A área total do império africano (2.056.771,22 $\mathrm{Km}^{2}$ ) correspondia a mais de 22 vezes o tamanho do velho reino e suas ilhas adjacentes (Açores e Madeira).

Apesar de ser um dos maiores impérios coloniais europeus da época, o ultramar português mantinha uma fraqueza: o vínculo à uma metrópole de escassos recursos econômicos, militares e demográficos (ALEXANDRE, 2000: p.184). Dependente de uma fraca agricultura e de uma emigração crônica para o Brasil, Portugal encontrava-se aquém das potências industriais-capitalistas que disputavam por territórios na África e na Ásia e as colônias portuguesas foram alvo de partilha entre britânicos e alemães em 1898 e 1913 e, em 1890, o ultimato britânico gorou o sonho português de possuir uma vasta colônia africana com a união dos territórios de Angola e Moçambique, projeto colonial que ficou conhecido como o Mapa Cor de Rosa. A despeito da estratégia diplomática portuguesa em torno da defesa dos "direitos históricos" do país, pois a presença lusitana na África remontava ao século $X V$, o controle de Lisboa sobre extensas possessões foi preservado, em parte, devido à incapacidade de seus rivais em entrar em acordo sobre a divisão do ultramar português(HOBSBAWN, 2003: p.89).

Entre as décadas de 1880 e 1910 o continente africano foi repartido em colônias controladas pelaGrã-Bretanha, França, Alemanha,Bélgica, Itália, Espanha e 
Portugal. A formação destes impérios impostos à África esbarrou em obstáculos representados pelas acirradas disputas entre as próprias potências imperialistas, pelas resistências das populações nativas e pelas doenças que ameaçavam dizimar a potencial mão de obra local. Para combater estas últimas, os europeus confiavam no vigor de sua medicina, na época profundamente influenciada pela microbiologia, mas também como uma importante ferramenta para servir à pretensa "superioridade" da civilização ocidental diante da "barbárie" e da "selvageria" dos povos africanos:

[...] o que se torna indispensável, de acordo aliás com as irrefutáveis conclusões a que chegou a ciência, sobre etiologia patogénica e modos de transmissão das doenças exóticas, é que a África deixe de ser uma região ameaçadora para o branco e se transforme num país salubre e adequado à felicidade e à multiplicação do preto (MARTINS, 1910: p.256).

Doenças como a malária, a oncocercose, a ancilostomíase, a esquistossomose, a febre amarela e a doença do sono foram incorporadas à nova especialidade médica que se constituía naqueles anos: a medicina tropical. Nos principais países colonizadores europeus foram criados institutos voltados para a instrução de médicos tropicais: na Grã-Bretanha, pioneira neste quesito, com a LiverpoolSchoolofTropicalMedicine (1898) e a London Schoolof Tropical Medicine (1899); na Alemanha com HamburgerInstitutfürSchiffs-undTropenkrankheiten(1900); em Portugal com a Escola de Medicina Tropical de Lisboa (1902); na França com a ÉcoleduPharo(1905) e, em 1906, os belgas com o InstitutdeMédecineTropicale(AMARAL, 2008:p.301-328).

Apesar da questão colonial estar no cerne da medicina tropical europeia, havia certas especificidades no discurso médico em cada país europeu, que evidenciavam sua posição no cenário africano: para Patrick Manson o interesse britânico pela medicina tropical era justificado pela importância de seu império, o maior do planeta, e a formação médica nesta área era necessária para manter a GrãBretanha na liderança mundial (MANSON, 1897:p.842-845); já o médico e parlamentar alemão Rudolf Virchow duvidava da possibilidade de aclimatação de seus conterrâneos em regiões tropicais, porém os germânicos confiavam no poder de sua crescente indústria farmacêutica para a produção de medicamentos que pudessem eliminar as doenças tropicais que encontravam em suas colônias e 
contornar as dificuldades enfrentadas pela Alemanha para manter seu império colonial (CORREA, 2012:p.1-23).

No entanto, para os portugueses, empenhados em defender seus "direitos históricos" sobre a África e tê-los reconhecidos por seus pares europeus, a longevidade de sua presença no continente africano confundia-se com as contribuições portuguesas para a medicina tropical, que remontariam ao século $\mathrm{XVI}$ através dos estudos das doenças encontradas nos trópicos como acólera, o escorbuto, a febre amarela e a sífilis. Evidentemente que tal interpretação fez parte de uma estratégia política para afirmação colonial do país, visto que a medicina nos trópicos do século XVI pouco se assemelhava à medicina tropical do século XIX.

A contribuição portuguesa para o avanço da medicina tropical remonta ao século $X V I$ e foi realmente importante. [...] Ao contrário do que se afirma, a contribuição portuguesa para o progresso da medicina tropical foi enorme e demonstra que, nas Ciências Biológicas, como nas Matemáticas, estavam os portugueses da Renascença à altura da missão que thes coube (FRANÇA, 1925: p.85-92).

Este desejo a afirmação de Portugal como potência pioneira na África e a necessidade de recuperação do orgulho nacional, arranhado após o ultimato britânico, estiveram na origem da determinação das autoridades portuguesasem enviar para as colônias africanas a primeira missão científica europeia com o intuito de estudar a etiologia da doença do sono em 1901.

\section{Uma doença africana relatada e potencializada por europeus}

Apesar de observada pelos europeus nos corpos dos negros da costa da Guiné desde o século XVIII, as origens da estranha doença marcada pela invencível sonolência foram atribuídas entre os séculos XVIII e XIX a diversos fatores: a influência nefasta do clima tropical sobre os homens, a fome, os excessos alcoólicos, as fadigas excessivas, a intoxicação alimentar provocada pela ingestão de mandioca crua, ou então pelas "paixões tristes" que acometiam os nativos quando eram retirados de suas cabanas no interior das florestas. Em conjunto com a variada etiologia, a doença conheceu inúmeras denominações: mal do sono, hidropisia narcótica, sono letárgico e doença do sono (VELHO, 1921: p. 23-24). No que tange às colônias portuguesas, em 1855 a doença era apontada como uma das principais 
aflições da população do porto de Bissau, na Guiné, e em Angola casos da doença foram registrados na década de 1870 (HAVIK, 2014: p. 641-666).

Embora fosse endêmica da África subsaariana, as condições brutais da ocupação europeia contribuíram para a instauração de uma epidemia de doença do sono entre 1900 e 1905. Argumentando que levariam povos "selvagens" e "atrasados" à civilização, os europeus impuseram uma rotina de trabalhos pesados às populações locais. As riquezas da África como a borracha, o ouro, o cacau e o cobre foram extraídas de maneira atroz mediante o recurso compulsório à força laboral das populações nativas, desviadas de suas atividades agrícolas tradicionais, sob orientação dos colonizadores. A exaustão provocada pelos trabalhos impostos e a nutrição cada vez mais baixa das populações indígenas minavam rapidamente a resistência de seus corpos frente às doenças locais. Para responder às crescentes exigências de borracha, muitos homens foram obrigados a percorrer longas distâncias no seio das florestas tropicais, em contato direto com as moscas tsé-tsé; as plantações de banana e de cacau, destinadas à exportação e próximas aos estabelecimentos humanos, criaram um excelente ambiente para as glossinas; e os deslocamentos populacionais, alguns facilitados pelas ferrovias, potencializaram o trânsito de pessoas de áreas contaminadas para áreas indenes (LYONS, 1992:p. 32$51)$.

As intervenções promovidas pelos europeus no ecossistema e na rotina das comunidades africanas, potencializaram a dimensão da doença do sono. Assim, os primeiros anos do século XX presenciaram uma epidemia no Congo Belga, em Angola e em Uganda, protetorado britânico onde a doença dizimou cerca de 250.000 pessoas (FÈVRE;etall, 2004,p: 567-573).

Diante do grave cenário que ameaçava destruir a mão de obra local empregada para a extração das riquezas do continente, bem como obstaculizar a viabilidade dos impérios europeus, tornava-se necessário combater a doença do sono e conhecer a sua origem etiológica. Mas, qual foi o país europeu que deu o primeiro passo em estudar a doença do sono in loco no laboratório a céu aberto em que a África foi transformada? Ora, justamente o país europeu que estava há mais tempo em solo africano, aquele que mantinha um império considerado desproporcional diante de suas precárias condições econômicas e militares e aquele 
que se esforçava por defender seu quinhão diante da cobiça de seus concorrentes mais poderosos: o Reino de Portugal.

\section{A busca pela etiologia da doença do sono e os primeiros passos da medicina tropical portuguesa}

No início de 1901 o governo português decidiu enviar para Angola e ilha do Príncipe uma missão de estudos constituída por bacteriologistas para desvendar a etiologia da temida doença e contribuir para reforçar a presença de Portugal enquanto potência colonizadora atuante na África. O grupo era composto pelos seguintes cientistas portugueses: Annibal Bettencourt, diretor do Instituto Bacteriológico e chefe da missão; Annibal Celestino Corrêa Mendes, médico do quadro de saúde de Angola; Ayres Kopke, diretor do laboratório microbiológico do Hospital da Marinha; José Gomes de Rezende, médico militar do Instituto Bacteriológico e João Brás de Gouveia, preparador do mesmo instituto (AMARAL, 2015: p.15).

Em seus trabalhos, transcorridos entre maio e agosto de 1901, a equipe examinou 27 doentes, cinco na ilha do Príncipe e o restante em diferentes partes de Angola, e realizou 13 autópsias. Após a realização de exames microscópicos de amostras do líquido cefalorraquidiano, de sangue e do fluido linfático, os bacteriologistas portugueses encontraram microrganismos "dispondo-se aos pares, mais ou menos arredondados, às vezes um pouco elípticos" e concluíram que a doença do sono era uma meningoencefalite de natureza microbiana (A DOENÇA, 1901: p.237-238).

Os cientistas retornaram à Lisboa com 21 pacientes portadores da doença do sono que seriam encaminhados ao Instituto Bacteriológico Câmara Pestana para a continuação de seus estudos e foram recebidos como verdadeiros heróis nacionais: "o resultado obtido pela comissão honra sobremodo a ciência médica de Portugal e constitui um dos seus melhores triunfos nos modernos tempos (O SÉCULO, 1901: p.3) ". No entanto, os resultados obtidos pelo grupo de Bettencourt foram envoltos em uma acirrada controvérsia científica desenrolada nos planos nacional e internacional: o primeiro envolveu um debate com bacteriologistas da Universidade de Coimbra que argumentavam terem identificado o mesmo microrganismo em amostras obtidas de dois doentes africanos do sono que foram remetidos à Coimbra no final do século 
XIX. No plano internacional a polêmica em torno da origem da doença contrapôs os resultados da missão de Bettencourt aos obtidos por pesquisadores a serviço da GrãBretanha.

Entre 1902 e 1903 a Royal Society of London patrocinou pesquisas em Uganda em torno da doença do sono e um outro microrganismo foi identificado por um dos membros da missão, o italiano Aldo Castellani, que, em confronto aberto com Bettencourt, reivindicou ter descoberto o verdadeiro agente etiológico da doença. No entanto, no final de 1902, Castellani observou tripanosomas no líquido cefalorraquidiano de doentes do sono, o que interessou David Bruce, pesquisador britânico notabilizado por seus trabalhos em torno da Nagana, a tripanossomíase animal. Estes parasitos eram muito similares aos observados pelos ingleses Joseph Dutton e Robert Forde no sangue de um doente febril na região do Gâmbia em 1901. $\mathrm{Na}$ altura, a estranha doença foi denominada de febre tripanosoma e o parasito de Trypanosoma gambiense, mas nenhuma relação foi aventada entre sua ação no organismo humano e a doença do sono.

A partir de 1903 a controvérsia científica caminhou em direção ao descrédito da teoria bacteriológica - apostada pelos portugueses - conforme os trabalhos coordenados por David Bruce confirmaram a unicidade etiológica entre a febre tripanosoma e a doença do sono. Se o tripanosoma era a causa da doença do sono, então a infecção não poderia ser transmitida pelos alimentos ou pela vestimenta e as suspeitas recaíram sobre a ação de algum inseto hematófago que pudesse servir como o vetor da doença. As desconfianças apontaram para as moscas tsé-tsé - as mesmas responsabilizadas por Bruce como as transmissoras da Nagana (A DOENÇA, 1903: p.384).

Ayres Kopke, integrante da missão de 1901, explicou, trinta e cinco anos depois, os motivos da ausência de êxito dos portugueses em identificar a etiologia da doença do sono:

A missão portuguesa não alcançou o êxito desejado porque nessa data a orientação dos que se dedicavam entre nós aos trabalhos laboratoriais sobre doenças parasitáriasera conforme à de Câmara Pestana, principalmente no sentido da bacteriologia e não no da protozoologia, não vulgarizada ainda entre os nossos médicos. Natural era pois a tendência para considerar as bactérias como os maiores inimigos e de lhes atribuir papel preponderante na etiologia das doenças contagiosas (KOPKE, 1936: p.13). 
Com o desfecho da controvérsia, a doença do sono passou a ser tratada como uma tripanossomíase humana, transmitida pela picada de dípteros hematófagos de hábitos diurnos e pertencentes principalmente à espécie Glossina palpalis - as moscas tsé-tsé. Estes insetos habitavam regiões nas proximidades dos cursos d'água que percorriam as matas ciliares das florestas úmidas, com cobertura vegetal abundante, sombria e perene, localizadas do Senegal até Benguela.

Quanto ao quadro sintomático da doença do sono, o mesmo apresentava três fases coincidentes com o desenvolvimento do tripanosoma sobre o organismo humano: quando o parasito se encontrava na corrente sanguínea, no início da doença, o enfermo apresentava estado febril e aumento dos gânglios linfáticos do pescoço; no segundo estágio o tripanosoma atingia o Sistema Nervoso Central a partir do líquido cefalorraquidiano provocando o sintoma característico da doença: o adormecimento invencível do doente durante suas atividades mais triviais, como ao longo de uma conversa ou no meio das refeições e com o alimento ainda em sua boca; por fim verificava-se a inflamação das meninges cerebrais, o que levava ao coma e à morte do indivíduo (AMARAL, 2012:p.1278).

Durante os anos da controvérsia a medicina tropical foi institucionalizada em Portugal com a criação da Escola de Medicina Tropical de Lisboa, em conjunto com o Hospital Colonial, em abril de 1902. O objetivo da escola era promover "a educação profissional dos facultativos dos quadros de saúde das províncias ultramarinas e dos médicos navais" (PINA, 1958: p.471) e seu financiamento provinha de um orçamento correspondente a $1 \%$ da receita anual das câmaras municipais das províncias ultramarinas. A escola de medicina tropical existiu até 1935, ano em que foi criado o Instituto de Medicina Tropical, e neste período instruiu pouco mais de 700 médicos (AZEVEDO, 1952:p. 97-110).

Os primeiros anos de existência da escola foram marcados pelo vulto de Ayres Kopke que se notabilizou por seus estudos em torno do Atoxy em 1906 - um composto orgânico arsenical capaz de destruir os tripanosomas enquanto estivessem na corrente sanguínea - como ferramenta terapêutica para combater a doença do sono. Este importante personagem da medicina tropical portuguesa esteve presente em eventos de importância internacional como o XV Congresso Internacional de Medicina em Lisboa, 1906; XIV Congresso de Higiene e Demografia em Berlim, 1907; duas Conferências Internacionais sobre doença do sono em Londres, 1907 e 1925; o 
XVI Congresso Internacional de Medicina em Budapeste, 1909; foi convidado por Patrick Manson para integrar uma comissão técnica internacional sobre doença do sono ao lado de Alphonse Laveran e Paul Ehrilich; era o único português eleitor do cobiçado prêmio Schaudinn - concedido pelo HamburgerlnstitutfürSchiffsundTropenkrankheitena cada 4 anos ao autor da descoberta mais significativa no âmbito da protozoologia; e ainda foi diretor da Escola de Medicina Tropical de Lisboa entre 1928 e 1936. Portanto, tratava-se de uma figura detentora de um vasto currículo e bastante conhecido no seio da comunidade científica internacional sobre medicina tropical.

A doença do sono ocupou um lugar de destaque na agenda científica da Escola de Medicina Tropical de Lisboa, sendo que a maioria das missões apoiadas pela escola na África destinou-se a estudar ou combater a tripanossomíase humana africana: Príncipe 1904, 1907 e 1911; Moçambique 1910 e 1928 e Guiné 1932 (AMARAL, 2008: p.312-318).

\section{A medicina sob as lentes do Darwinismo social}

De definição precisa problemática a expressão Darwinismo social geralmente significa a transposição para o campo das ciências sociais e políticas das ideias do evolucionismo, em especial a luta pela existência e a seleção natural. O termo foi inicialmente empregado para se referir à luta entre indivíduos dentro de uma sociedade, onde os mais aptos prevaleceriam, mas no final do século XIX passou a ser encarado como uma competição entre grupos raciais necessária para a evolução da Humanidade (BECQUEMONT, 2011: p.12-19).

O Darwinismo social esteve em voga em um contexto histórico de disputas entre indivíduos e nações e marcadamente racista, embalado pela noção de hierarquia racial onde o branco encarnou o papel do civilizado, do inventivo, do perspicaz, do governado pelas leis e, como sua antítese, o termo africano ganhou materialidade precisa: o homem negro do qual se atribuiu um amplo espectro de significações negativas: indolente, frouxo, incapaz, infantil, manhoso, preguiçoso e negligente, denominações que convergiam para uma imagem de inferioridade e primitivismo (HERNADEZ, 2008: p.18-19). Esta doutrina de superioridade racial interagiu com ideias de dominação política e marcou indelevelmente a formação dos impérios europeus na África. 
A medicina, entendida aqui como uma prática técnica e social, refletia o mito da superioridade branca e da selvageria negra, sendo encarada como um instrumento fundamental para o domínio europeu sobre as sociedades africanas não apenas pela crença em seu poder para propor soluções aos problemas de saúde pública, mas, também, como forma de conhecer e atrair as populações indígenas para a esfera de influência europeia:

A assistência médica ao indígena, constitui, para os povos colonizadores, não só uma das principais responsabilidades que estes assumem como mentores das raças inferiores, mas também um dos meios auxiliares mais frutíferos de infiltração, aquisição de prestígio e garantia de predomínio sobre seus tutelados.

Poucos benefícios, de entre aqueles que para os povos selvagens resultam da sua sujeição às raças superiores, serão tão facilmente reconhecidos e sentidos, como os que podem advir de uma assistência médica bem organizada e efetivada (SANT'ANA, 1923: p. 73).

A corporação médica entendia a assistência prestada aos indígenas como civilizatória e necessariamente benéfica diante das agruras vividas pelos nativos em um meio hostil.

A assistência médica é uma das formas mais eficazes de demonstrarmos ao indígena a nossa desinteressada proteção. Ele pode duvidar da utilidade de muitos empreendimentos, de que não compreende senão o trazerem-lhe um acréscimo de trabalho físico. Mas não duvidará das nossas boas intenções quando elas se traduzem em curarmos-lhes uma doença, salvarmos-lhes um filho da morte, e a evitarmos-lhe o perigo de um contágio fatal (MORA, 1921:p. 6).

Apesar do discurso altruísta, a medicina no império contava com muitos empecilhos a começar pela falta de clínicos, um relatório sobre o quadro de saúde das colônias de 1909 apontou que em Angola, com uma área de 1.255 .775 Km² e uma população total de aproximadamente 4.000 .000 de habitantes, havia apenas 45 médicos, 10 farmacêuticos e 96 auxiliares: enfermeiros, ajudantes e serventes (MARTINS, 1910: p.243). Se as colônias não eram o destino almejado pela maioria dos médicos formados pela Metrópole, o que se dirá sobre os seus sertões, os recantos mais remotos do império?

É forçoso que se acabe com um erro, que com frequência se vê praticar nas colónias, tanto dentro dos serviços sanitários como em qualquer outro lugar ramo de administração europeia: os indivíduos de aptidões restritas, incapazes de assumirem um certo número de responsabilidades, cuja dedicação pelo trabalho deixa muito a desejar, são exatamente os que se destinam aos serviços do mato, sendo enviados para o interior a exercer as suas funções em contato direto com o indígena.

Nada mais desacertada do que esta seleção ao invés, quando se trata dos serviços interessando diretamente o nativo; toda a nossa ação colonial se 
ressente dos defeitos dum critério, com justiça classificável de lamentável e desastroso (SANT'ANA, 1923: p.80-81).

Mas quem eram estes indígenas? O termo africano reduz e simplifica todo um quadro complexo constituído por etnias espalhadas pelos cantos e recantos dos territórios coloniais, mas que também transitavam entre as fronteiras destes territórios colocados sob a soberania europeia. Alguns eram mais assimilados aos costumes e a presença dos brancos, outros mantinham contatos mais escassos com os colonizadores. As etnias que habitavam as paisagens das então colônias lusitanas tinham nome e identidade, eis alguns deles: em Angola havia os Mixicongos, os Cabindas, os Ovimbundus, os Cuanhamas; em Moçambique eram os Maraves, os Maganjas, os Batangas e na Guiné, os Fulas, os Papeis, os Cassangas, os Manjacos, os Oinças (EXPOSIÇÃO, 1940: p.34-192).

E os membros destas sociedades, assim como em outras em toda a África, possuíam saberes com técnicas e farmacopeias para o tratamento das doenças que Ihes afligiam. Entretanto, os médicos europeus desqualificavam estes conhecimentos e nomeavam os quibandas como meros feiticeiros ou curandeiros, com tom depreciativo, e não como guardiães de conhecimentos antigos e moldados com base nas necessidades locais.

Se por um lado os europeus nutriam grande confiança nas capacidades de sua medicina, os indígenas resistiam e olhavam com descrença as ações dos médicos metropolitanos, a começar pela língua que desconheciam o que tornava necessária a busca por intérpretes, mas também compreendiam as medidas profiláticas e terapêuticas como mais um elemento da colonização e mais um controle exercido sobre suas vidas (VARANDA, 2000: p.84). Pois as medidas de saúde prescreviam a remoção de aldeias inteiras para áreas distantes das glossinas; o agrupamento de pequenos povoados; o isolamento de doentes; a necessidade de submissão aos exames de sangue, do suco ganglionar e as dolorosas punções lombares; bem como o controle sobre os percursos utilizados pelos nativos para a fiscalização sanitária, ações que interferiam na rotina e nos hábitos das populações locais.

Embora esta pesquisa tenha recorrido às fontes que expressam o ponto de vista europeu, foi possível notar em suas linhas a relutância de muitos indígenas em se submeterem aos conhecimentos da medicina ocidental, optando pelos seus quibandas no momento da doença ou ainda quando recorriam aos médicos brancos 
solicitavam que fossem aplicados em seus corpos os mesmos procedimentos recomendados por seus curandeiros. Em 1932 foi organizada uma missão científica da Escola de Medicina Tropical à Guiné e parte destas queixas contra o comportamento dos nativos está registrada no documento a seguir:

O indígena recorre quase sempre a seus feiticeiros para tratamento desta doença [a doença do sono], que no início é denominada a pedra, em consequência do ingurgitamento e endurecimento de consistênciapétrea de que algumas vezes são atacados os gânglios cervicais e submaxilares. Os feiticeiros (curandeiros mandingas) fazem extração dos gânglios engorgitados, e é crença arreigada nos habitantes da Guiné, de que são essas pedras que lhes determinam o sono (RELATÓRIO, 1932: p. 8).

As crenças dos nativos em relação à origem da doença do sono, muitas vezes associadas ao mundo sobrenatural, também eram desqualificados pelo saber médico europeu, como apresentado no relatório sobre os trabalhos de combate às moscas tsé-tsé na ilha do Príncipe em 1913.

Cada casa indígena sustenta uma dúzia de cães em liberdade, para a
alimentação da "glossina" e dificilmente os indígenas atacados de hipnose
se sujeitam à sequestração e ao tratamento, para que é necessário serem
intimados administrativamente a comparecerem no hospital militar. Os
menos ilustrados ainda não acreditam que os seus patrícios estejam
atacados de hipnose, pois quando eles apresentam sintomas de sonolência e
alienação mental, dizem que é consequência do feitiço. Seja como for, todo
o cidadão tem de ser útil ao seu país e não é dormindo e andando em festas
que um povo se regenera (COSTA, 1913: p.68).

Outro aspecto que gerava resistências diante das medidas profiláticas impostas pelo saber europeu ao combate da tripanossomíase africana era a política de isolamento dos doentes do sono em hipnosarias, a semelhança das garrafarias para os doentes de lepra. No entanto, muitos indígenas, temerosos com as consequências do isolamento de seus familiares, ocultavam seus enfermos (SANT'ANA,1923:p.134-135). No Congo belga, por exemplo, diante do desaparecimento permanente dos doentes isolados, rumores corriam que os europeus devoravam as partes do corpo dos enfermos durante as autopsias e fabricavam seus remédios com as partes restantes (LYONS, 1992: p.90).

A doença do sono vitimou principalmente a população negra, casos de pacientes europeus foram registrados, mas eram mais raros. Argumentava-se que algumas das razões desta maior incidência estavam atreladas aos costumes dos indígenas em usar menos roupas, em comparação aos europeus, desta forma 
estariam mais expostos às picadas das glossinas ou ainda pela preferência das moscas por cores mais escuras.

As tsé-tsé são atraídas por objetos móveis, vivos ou não, e sempre por cores escuras tais como o preto e o caqui; elas fogem das cores claras. Esta é uma das razões pelas quais os negros são mais freqüentemente picados do que os europeus (BRUMPT, 1927: p.1011).

A despeito das explicações de cunho racista, outros fatores devem ser levados em consideração.Em primeiro lugar a população predominante nos domínios europeus na África era constituída pelos indígenas. No caso das colônias portuguesas, as autoridades políticas buscaram, em alguns momentos, promover o desvio da torrente emigratória destinada ao Brasil em benefício das possessões africanas a partir de incentivos efêmeros como um decreto de 1907 que suspendeu a obrigatoriedade dos passaportes àqueles que se destinassem aos territórios africanos sob administração portuguesa (PEREIRA, 2002: p. 86-87). No entanto, a partida de portugueses para a África, no lusco-fusco do século XIX e primeiras décadas do século $X X$, nunca foi comparável às dimensões da emigração para os portos brasileiros. O historiador Joaquim Oliveira Martins justificou à luz de sua época, o Portugal do findar do Oitocentos, o porquê que a África não estava entre as prioridades dos emigrantes:

Pela razão simples de em África se não carecer do trabalho branco, por isso que não faltam pretos para trabalhar por um jornal muito mais reduzido. [...] Por isso, é uma perigosa quimera a ideia de desviar para África a corrente de emigração de minhotos, madeirenses e açorianos, proletários, trabalhadores rurais analfabetos, que hoje vão em demanda de países onde os braços faltam, e que em África se veriam reduzidos a trabalhar em concorrência com as raças negras (MARTINS, 1994: p.195-196).

A questão do trabalho indígena forçado é vital para compreender a maior incidência da tripanossomíase humana africana entre os nativos, já que estes indivíduos eram requeridos para atividades braçais na colheita do café e do cacau, na extração do coconote ou no transporte do azeite de palma em áreas infestadas de glossinas. Assim, mais que uma doença "própria das raças negras" (RELATÓRIO, 1932: p.8), a incidência da doença do sono refletia as condições históricas, sociais e econômicas impostas pela dominação colonial, onde os corpos dos negros, muitas vezes exauridos pela dura rotina do trabalho, por uma alimentação deficiente e pelo consumo de água em mal estado, estavam mais expostos às picadas vorazes das glossinas e consequentemente à ação dos tripanosomas sobre seus organismos. 


\section{O combate à doença do sono à sombra do cacau escravo}

O que talvez tenha sido o maior feito da medicina tropical portuguesa na primeira metade do século XX ocorreu na ilha do Príncipe. A pequena colônia insular de São Tomé e Príncipe consolidou-se como uma importante produtora mundial de cacau, mas dependente da importação de mão de obra oriunda de Cabo Verde, de Moçambique e, principalmente, de Angola.

A legislação portuguesa, referente à mão de obra indígena, abria a possibilidade para o uso do trabalho forçado. Como se pode observar no Regulamento do trabalho dos indígenas de 1899:

Artigo $1 .^{\circ}$ Todos os indígenas das províncias ultramarinas portuguesas são sujeitos à obrigação, moral e legal, de procurar adquirir pelo trabalho os meios que thes faltem, de subsistir e de melhorar a própria condição social. [...]

Art. $31 .^{\circ}$ Os indígenas sujeitos à obrigação de trabalho, que não cumprirem voluntariamente por nenhum dos modos especificados no artigo 2. ${ }^{\circ}$, deverão ser intimados pela autoridade administrativa para trabalhar em serviço do estado, dos municípios ou de particulares, sempre que essa autoridade possa proporcionar-lhes trabalho. Se não obedecerem à intimação serão compelidos (REGULAMENTO, 1899: p.647 e 651-652).

De acordo com o princípio vulgarmente aceito na época, o trabalho seria uma ferramenta para civilizar "povos atrasados" e, evidentemente, a sua imposição aos nativos, seguindo uma disciplina de trabalho imposta pelos europeus, abria as portas para uma série de arbitrariedades e abusos. O uso da mão de obra local também era justificado pela pretensa inadaptabilidade do homem branco europeu ao clima africano e pela robustez dos corpos dos negros, que aos olhos dos colonizadores, estariam vocacionados ao trabalho pesado, sob supervisão de um branco.

[...] Ao preto, cabe e caberá sempre ali, o exclusivo de toda a casta de trabalhos que reclamem grande dispêndio de energias e tenham que se efetuar ao sol e no conflito com os múltiplos agentes físicos e animados que pululam por toda a parte; e isto, porque ele possui imunidades e passividades orgânicas que o preservam e o defendem, enquanto o branco, deslocado do seu meio e pelas condições peculiares da sua raça, se acha indefeso e exposto à agressão febril desses inimigos múltiplos, que não cansam de fustigá-lo e acabam quase sempre por vencê-lo.

Ao branco está reservada hoje, como sempre, em África, a superintendência e execução em todos os serviços que demandarem maior inteligência e menor esforço, maior competência e menor exposição (MARTINS, 1910: p.256). 
Apesar de ser uma importante produtora de borracha e café, além de ser a maior colônia portuguesa, Angola foi tratada como uma indispensável fornecedora de mão de obra para outros territórios coloniais lusitanos, uma reminiscência dos tempos do tráfico de escravos. A colônia ainda sofria com a doença do sono e registrava em seu território a presença (incômoda) das glossinas:

\begin{abstract}
Algumas entraram dentro do comboio em marcha e um companheiro de viagem, condutor do caminho de ferro de Malange, foi picado no pescoço por uma mosca que se conseguiu apanhar e que por um exame rápido e muito superficial me pareceu pertencer à espécie palpalis.

$\mathrm{Na}$ travessia entre Cassualalla e o Dondo, uma viagem de 6 horas em tipoia (rede transportada às costas dos pretos), as glossinas são abundantíssimas. A todo o instante pousavam na rede e nas costas dos carregadores, vendo-se estes obrigados de tempos a tempos a bater com a palma da mão nas costas para as afugentar, sucedendo muitas vezes esmagarem algumas já repletas de sangue, acabado de sugar[...]. Do Dongo segui para Massangano, povoação situada na margem direita do Cuanza, descendo o rio em escaler. Durante toda a viagem fui importunado pela tsé-tsé que invadia constantemente o barco, principalmente quando me aproximava das margens (MENDES,1905: p.68-69).
\end{abstract}

Os indígenas recrutados para os trabalhos braçais, sob a supervisão dos colonizadores, eram denominados de serviçais. Além de ser entendido como uma obrigação moral pela legislação portuguesa, o trabalho era encarado também como uma punição imposta aos condenados por crimes pelas autoridades coloniais. A relação entre os colonizadores e as populações nativas foi permeada por arbitrariedade, por exemplo, um dos motivos da guerra Luso-Ovimbunda de 1902 foram as armadilhas colocadas pelos portugueses para capturar os nativos e submetê-los aos trabalhos forçados. Estas emboscadas funcionavam da seguinte forma: alguns comerciantes ou militares portugueses fingiam abandonar garrafas de aguardente ou barris de pólvora e, quando os nativos se aproximavam destes itens supostamente abandonados, eram surpreendidos e condenados por delito de furto (PINTO, 2017: p.623).

O principal destino dos serviçais ou angolas eram as ilhas de São Tomé e Príncipe. Como este arquipélago foi, historicamente, um ponto de escala relevante das rotas marítimas entre o continente africano e o Brasil ou a Europa, acredita-se que este tráfego tenha levado às ilhas exemplares de glossinas - esta explicação, inclusive, era defendida pelos naturais que chamavam as tsé-tsé de moscas do Gabão, referência geográfica à localidade do continente mais próxima de São Tomé e Príncipe. As moscas teriam se adaptado muito bem às condições climáticas e 
ambientais do Príncipe e o envio constante de serviçais das regiões endêmicas angolanas para trabalhar nas roças cacaueiras de uma pequena ilha onde as moscas tsé-tsé proliferavam teve um resultado: a formação de uma grave epidemia de doença do sono.

Embora de pequenas dimensões $\left(142 \mathrm{Km}^{2}\right)$ na ilha do Príncipe dois pontos importantes do colonialismo português na África se encontraram: a ameaça representada pela doença do sono e as pressões internacionais da campanha antiescravagista contra Portugal. O transporte marítimo dos indígenas de Angola e Cabo Verde para o Príncipe e as condições de trabalho impostas nas roças despertaram denúncias das autoridades de países europeus quanto à tênue diferença entre as categorias de serviçais e de escravos nos domínios lusitanos. Um dos episódios centrais desta campanha foi a decisão do chocolateiro britânico William Cadbury de suspender a compra do cacau proveniente de São Tomé e Príncipe em 1908, depois de visitar as roças cacaueiras do arquipélago (SATRE,2005:p.146).

Se as acusações de encobrimento da escravidão representavam uma ameaça ao domínio de uma fraca metrópole - visto que serviam para questionar a "missão civilizadora" de Portugal, embora os abusos cometidos contra as populações nativas tenham sido reportados também em outras colônias europeias - o abandono de uma possessão, mesmo que com graves problemas sanitários, seria como que admitir o "fracasso" dos portugueses como uma nação colonizadora perante seus pares europeus, o que estava definitivamente fora de cogitação para as novas autoridades republicanas que detinham o poder em Lisboa desde outubro de 1910 após a deposição do último rei português, D. Manuel II. Desta forma, o Príncipe emergiu como um palco onde se desenrolaria uma história que poderia resultar no "triunfo" ou no "malogro" da colonização portuguesa e a campanha de erradicação das glossinas nesta ilha, desencadeada em 1911, não deve ser apartada de todo este contexto.

Em fevereiro de 1911, por iniciativa do governo colonial de São Tomé e Príncipe, os proprietários de terrenos ficavam obrigados a proceder na capinação e na derrubada das florestas em suas propriedades, a criação de porcos foi estritamente proibida na ilha, redes metálicas deveriam ser instaladas em portas e janelas das habitações, prescrevia-se aos serviçais o uso de vestimentas de cor clara que cobrissem inteiramente o corpo, dos pés à cabeça, e todos aqueles que fossem 
picados por glossinas estavam sujeitos à obrigatoriedade da aplicação de injeções de Atoxyl.

O governo provisório da República em Lisboa, que na altura tinha pouco mais de seis meses de existência, aprovou um decreto em 17 de abril de 1911 que reforçou as disposições estabelecidas pelas autoridades coloniais no que tange ao combate da doença do sono no Príncipe. O assunto sobre os estragos causados pela tripanossomíase humana na pequena colônia provocou acesos debates no parlamento e algumas propostas como a exigência de exames médicos microscópicos aos serviçais que se destinassem ao trabalho nas roças da ilha, bem como a impossibilidade de retorno para a terra natal daqueles que fossem acometidos pela doença no Príncipe, que foram aprovadas e transformadas em lei (COSTA, 1915: p.62-63).

A metrópole ainda aprovou a constituição de uma brigada oficial composta teoricamente por 300 serviçais e submetida a um diretor técnico para proceder nos trabalhos de saneamento como a caça às glossinas, drenagem de pântanos e limpeza dos terrenos. Uma missão médica foi encaminhada ao Príncipe, seu principal objetivo era coordenar os trabalhos sanitários que deveriam eliminar as glossinas e Bernardo Bruto da Costa, médico goense e diplomado pela Escola de Medicina Tropical em 1904, foi nomeado seu comandante a partir de agosto de 1912. Os relatórios dos trabalhos sanitários desenvolvidos na ilha foram publicados em periódicos portugueses como o Portugal Médico e um número inteiro dos Arquivos de Higiene e Patologia Exóticas- principal publicação da Escola de Medicina Tropical de Lisboa dedicou suas páginas aos pormenores da campanha, em 1915.

Embora a geografia do Príncipe - uma pequena ilha no golfo da Guiné tenha conspirado a favor da missão médica por permitir um controle sanitário mais acirrado sobre o território, seus trabalhos não se resumiram a uma sucessão linear de eventos bem-sucedidos, mas foram permeados por resistências e dificuldades.

Um dos primeiros obstáculos foi a escassez de braços para compor a brigada oficial, que começou seus trabalhos em fevereiro de 1911 com apenas 43 homens recrutados majoritariamente entre os prisioneiros de guerra e os condenados por crimes em São Tomé, em Angola e na Índia. O efetivo empregado nesta brigada aumentou lentamente ao longo dos anos, atingiu sua primeira centena em junho de 
1911 e a cifra dos 300, exigida por lei, apenas foi alcançada em abril de 1914 (COSTA, 1915: p.75).

O combate à doença do sono incidiu principalmente na intervenção humana através da destruição do habitat das glossinas, desta forma o pessoal da brigada foi mobilizado para a drenagem e aterro dos pântanos, derrubada das florestas e destruição da vegetação herbácea e arbustiva, inclusive aquela próxima das margens dos rios, por meio do machado e das queimadas. A limpeza dos terrenos, como era chamada, deveria ser procedida também nos cacaueiros, locais igualmente infestados pelas tsé-tsé, mas como a legislação isentava os proprietários com poucos serviçais dos custos de tais operações, muitos donos de terrenos dispensaram seus empregados para não ter que arcar com os gastos de capinação, transferindo-os para a brigada oficial. Os relatórios produzidos acusavam constantemente os proprietários indígenas de indolência e passibilidade frente aos trabalhos prestados:

No abandono em que os Indígenas, salvo raras exceções, trazem as suas propriedades, demonstram bem a sua indolência natural que aumentou quando tiveram conhecimento de que não pagavam nada, dos serviços feitos pela brigada, aqueles que não possuíssem trabalhadores nas suas propriedades. Achamos extraordinário que havendo aqui uma liga indígena, esta não tenha feito compreender aos patrícios menos inteligentes a necessidade que há de acabar com a doença do sono, evitando assim o aniquilamento da sua raça. Notamos somente da parte dos indígenas um indiferentismo doentio (COSTA, 1913: p.68).

É importante frisar que as críticas elaboradas pelos médicos portugueses aos habitantes locais de uma colônia africana devem ser compreendidas sob as lentes do imperialismo europeu que, em via de regra, considerava os nativos de suas colônias como seres racialmente inferiores e menos vocacionados ao trabalho em comparação ao homem branco, sendo a expressão "indolência natural" utilizada no discurso acima bastante elucidativa. No entanto, foram os habitantes da ilha que bancaram a maior fatia dos custos dos trabalhos da missão, avaliados em $156.982 \$ 27$ Escudos (COSTA, 1915: p.129).

Além do desmatamento, outra medida tomada para a erradicação das moscas na ilha consistiu na eliminação de alguns mamíferos, em especial os porcos. Como a criação de suínos foi proibida no Príncipe, muitos dos donos dos currais decidiram abandonar suas criações que, soltas e perseguidas pela brigada, refugiaram-se no interior das florestas.

É sabido de todos que a mosca se acoita nos pontos sombrios, úmidos e habitados por animais, principalmente pelo porco, que não reagindo 
àpicada das moscas deixa pousar estas em grande número e as leva à distância. Este animal, além de veículo serve-lhes de bom campo de alimentação, por serem hematófagas.

De uma vez observamos num porco morto 30 "glossinas" agarradas e cheias de sangue e sempre que são mortos aqueles animais a tiro, segundo informação do primeiro capataz da brigada, encontram-se lhes algumas "glossinas" agarradas ao corpo (COSTA, 1913: p.68).

Os porcos não foram os únicos alvos da campanha sanitária, sendo que cães vadios e lagaias também foram sacrificados. O extermínio de animais em áreas endêmicas de glossinas era recomendado na época como medida profilática eficaz no combate à doença do sono, visto que os europeus argumentavam que os animais selvagens poderiam servir como reservatórios de tripanosomas e alimento para as moscas. Nesta seara, Robert Koch, em uma visita à colônia alemã de Tanganica, defendeu a extinção dos crocodilos em 1908 (LYONS, 1992:p.51).

Como medida complementar às ações da brigada foi utilizado o método de Maldonado, que consistia no uso de panos embebidos em substâncias viscosas sobre as costas dos serviçais para a captura das moscas. Seu uso na eliminação das glossinas requeria alguns cuidados já que não poderia ser usado na mata fechada, sob a pena de capturar as folhas das árvores no lugar das tsé-tsés. Assim, os supervisores da brigada escalavam os homens considerados mais robustos para a função de machadeiros empregados na derrubada das árvores das florestas e, nas clareiras abertas, os outros serviçais eram orientados a caminhar de um lado para o outro portando um pano viscoso nas costas para a captura das moscas que fugiam do desmatamento.

Os homens mobilizados na brigada, em contato direto com as glossinas, eram submetidos a doses quinzenais de $0,6 \mathrm{~g}$ de Atoxyl e aqueles empregados nas roças cacaueiras, caso fossem picados, deveriam comunicar as autoridades médicas para receber doses profiláticas do composto arsenical e, talvez para incentivá-los, eram liberados do trabalho no dia da aplicação hipodérmica da droga. No entanto, o uso desta substância poderia provocar sintomas de intoxicação como vômitos e, nos casos mais graves, o aparecimento de lesões oculares que levavam à cegueira: "toda a gente está atualmente de acordo em que a cegueira aparecida no decorrer da doença do sono deve ser atribuída, quase exclusivamente, à medicação atoxylica empregada para a combater" (PINTO, 1911: p.31). 
Coube ainda à equipe médica a realização de exames microscópicos em amostras de sangue dos habitantes da ilha e quando havia a presença do Trypanosoma gambienseno organismo, o doente era submetido ao tratamento atoxílico e isolado. O parecer sanitário negativo para a doença do sono tornou-se imprescindível para a entrada e para a saída do Príncipe, e os serviçais que apresentassem o parasito no sangue ou no líquido cefalorraquidiano eram proibidos de deixar a ilha, mesmo após o fim de seu contrato, condenados a permanecer em uma prisão insular, sob o controle de seus patrões, até o final de suas vidas. 0 trabalho árduo nas roças, a ameaça representada pela doença do sono e a impossibilidade de muitos serviçais deixarem a ilha com vida explicam o porquê de São Tomé e Príncipe ser conhecida como terra de desterro pelas populações nativas de Cabo Verde e Angola (BERTHET, 2016: p.345)

Com o ataque sistemático a seu ecossistema o número de moscas tsé-tsé declinou na ilha: em 1911 foram capturados 203.629 dípteros; no ano seguinte 197.326; em 1913 foram mortas 68.322 moscas e em 1914 a cifra atingiu 34 exemplares e, a partir de maio daquele ano, o índice de capturas zerou (COSTA, 1915: p.115). Em junho de 1914 a ilha foi considerada livre de moscas tsé-tsé, tal fato foi reverberado pela memorialística médica e serviu para enaltecer a presença colonial portuguesa na África, como no texto escrito pelo filho de Bernardo Bruto da Costa.

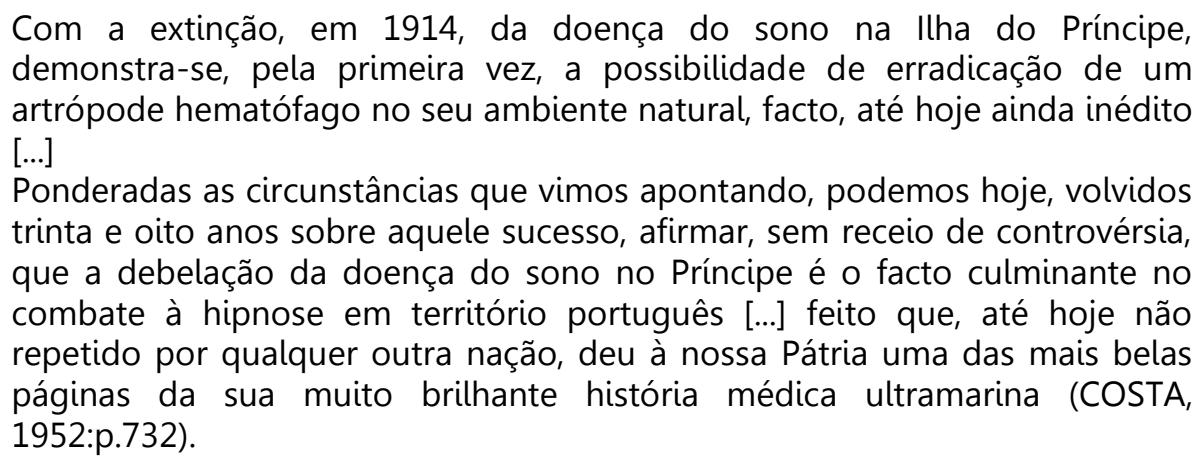

O Príncipe permaneceu livre das moscas tsé-tsé até 1956, ano em que uma nova infestação de glossinas atingiu a ilha e outra campanha de erradicação foi montada, que resultou na eliminação das moscas em 1958 (AZEVEDO,1964:p.11).

\section{Considerações finais}

Este artigo buscou abordar como a medicina, em especial a medicina tropical, constituiu-se como uma ferramenta para o exercício do colonialismo 
português na África. Através do estudo e do combate das doenças que grassavam em suas colônias, potencializadas pela ação colonizadora, e a doença do sono foi o caso aqui abordado, Portugal buscou conseguir o reconhecimento do status de potência colonial e "civilizadora" por seus pares europeus e minimizar as ameaças de partilha de seu império colonial. Ao mesmo tempo, a atuação dos médicos portugueses procurou ampliar os tentáculos metropolitanos sobre os territórios ultramarinos e colocar as populações nativas sob a influência dos saberes e das práticas médicas ocidentais, o que não ocorreu sem resistências por parte destas mesmas populações.

\section{Referências Bibliográficas}

A DOENÇA do somno. A Medicina Contemporânea. Lisboa, ano 19, n.40, 6 out. 1901.

A DOENÇA do somno. A Medicina Contemporânea. Lisboa, ano 21, n.48, 29 nov. 1903.

A DOENÇA do somno. O Século, Lisboa, 8 out. 1901.

ABRANCHES, Pedro. O instituto de higiene e medicina tropical. Um século de história 1902-2002. 3.ed. Lisboa: fundação Calouste Gulbenkian. 2002.

ALEXANDRE, Valentim. Velho Brasil novas Áfricas. Portugal e o império (1808-1975). Porto: Afrontamentos, 2000.

AMARAL, Isabel. Emergenceof tropical medicine in Portugal: theschoolof tropical medicine andthe colonial hospital ofLisbon. In:Dynamis, v.28, 2008.

AMARAL, Isabel. Bactéria ou parasita? A controvérsia sobre a etiologia da doença do sono e a participação portuguesa, 1898-1904. In: História, Ciências, SaúdeManguinhos. Rio de Janeiro, vol.19, n4, 2012-b. p.1275-1300.

AZEVEDO, João Fraga. Cinquenta anos de atividade de instituto de medicina tropical. Lisboa, 1952.

AZEVEDO, João Fraga. Estado actual e perspectivas futuras do problema das tripanossomíases africanas. Anais do Instituto de Medicina Tropical, Lisboa, v.21, n.1, 1964.

BECQUEMONT, Daniel. Social darwinism: from reality tomythandfrommythto reality. In: Studies in historyandphilosophyofbiologicalandbiomedicalsciences. v.42, 2011.

BERTHET, Marina. À sombra do cacau. representações sobre o trabalho forçado nas ilhas de São Tomé e Príncipe. In: Revista do Arquivo Geral da Cidade do Rio de Janeiro, Rio de Janeiro, n.11, 2016. Disponível em: 
http://wpro.rio.rj.gov.br/revistaagcrj/wpcontent/uploads/2016/12/Dossi\%C3\%AA_Artigo-2.pdf .

COSTA, Bernardo Bruto. Trabalhos sobre a doença do somno. Saneamento, estatística, serviços hospitalares e brigada oficial. Lisboa: A Editora Limitada, 1913.

COSTA, Bernardo Bruto, et.al. Relatório final da missão da doença do sono na ilha do Príncipe. Arquivos de Higiene e Patologia Exóticas, Lisboa, 1915.

COSTA, Vasco Bruto da. A olha do Príncipe e a doença do sono InAnais do Instituto de Medicina Tropical, Lisboa, v.9, n.3, 1952.

CORREA, Sílvio Marcus de Souza. O 'combate' às doenças tropicais na imprensa colonial alemã. In: História, Ciência, Saúde-Manguinhos, Rio de Janeiro, 2012. Disponível em: http://www.scielo.br/hcsm.

EXPOSIÇÃO do mundo português - Secção colonial. Lisboa: Neogravura,1940.

FRANÇA, Carlos. Os portugueses da renascença e a medicina tropical. In: Boletim da Agência Geral das Colónias. Lisboa: Agência Geral das Colónias, ano.1, n.2, 1925.

HAVIK, Philip Jan. Publichealthand tropical modernity: thecombatmagainstsleepingsickness In PortugueseGuinea, 1945-1975. História, ciência e saúde - Manguinhos, Rio de Janeiro, v.21, n.2, 2014.

HERNANDEZ, Leila Leite. A África na sala de aula. Visita à história contemporânea. 2.ed. São Paulo: Selo negro, 2008.

HOBSBAWN, Eric J. A Era dos Impérios, 1875-1914. Tradução de Sieni Maria Campos e Yolanda Steidel de Toledo. 8.ed. Rio de Janeiro: Paz e Terra, 2003.

KOPKE, Ayres. A política sanitária do império. Lisboa: Agência Geral das Colónias, 1936.

LUTZ, Adolpho. Considerações sobre a transmissão de doenças por sugadores de sangue. Folha Médica, Rio de Janeiro, 25 jul.1936.

LYONS, Maryinez. The colonial disease: a social historyofsleepingsickness in northen Zaire, 1900-1940. Cambridge: Cambridge University Press, 1992.

MARTINS, João Augusto. Revista sanitária das províncias ultramarinas. Referida ao ano de 1909. Archivos de Hygiene e PathologiaExoticas, Lisboa, v.3, 1910.

MARTINS, Joaquim Oliveira. Fomento rural e emigração. 3.ed.Lisboa: Guimarães editores, 1994.

MANSON, Patrick. Tropical diseases. A manual of diseases of warm climates. Londres: Casselsandcompany, 1900. (e-book).

MENDES, Annibal Corrêa. Glossinas de Angola. Arquivos de Higiene e Patologia Exóticas, Lisboa, v.1, 1905. 
MORA, António Damas. Circular da Repartição Superior de Saúde e Higiene aos Srs. Delegados e Subdelegados de saúde da província de Angola. Revista Médica de Angola, Luanda, n.1, 1921.

PEREIRA, Miriam Halpern. A política portuguesa de emigração (1850-1930). Bauru: Edusc/Instituto Cmões,2002.

PINA, Luís. Investigadores portugueses sobre medicina tropical. Anais do Instituto de Medicina Tropical, Lisboa, v.15, 1958.

PINTO, J. da Gama. As perturbações visuais na tripanossomíase. A Medicina Contemporânea, Lisboa, ano 29, jan.1911.

PINTO, Alberto Oliveira. História de Angola. Da pré-história ao início do século XXI. 2.ed. Lisboa: Mercado de letras, 2017.

RELATÓRIO da missão médica à colónia da Guiné. Trabalho de investigação científica realizado em 1932. Lisboa: Ministério das Colónias/ Escola de Medicina Tropical, 1932.

REGULAMENTO do trabalho dos indígenas de 9 de Novembro de 1899. Disponível em <http://www.fd.unl.pt/anexos/investigacao/1427.pdf>. Acesso em: 31 Mar.2018.

SANT'ANA, Firmino. O problema da assistência médico-sanitária ao indígena em África In Revista Médica de Angola. Número consagrado ao Primeiro Congresso de Medicina Tropical da África Ocidental. Lisboa: n.5, ago.1923.

SATRE, Lowell J. Chocolate ontrial: slavery, politics, andtheethicsof business. Athens: Ohio University Press, 2005.

VARANDA, Jorge. A Diamang e a doença do sono: um caso ímpar no colonialismo português. 94f. Estágio de investigação - Faculdade de Ciências e Tecnologia da Universidade de Coimbra, 2000.

VELHO, Luís Baptista da Assunção. A doença do sono como entidade mórbida. Revista Médica de Angola, Luanda, n.2, 1921.

Ewerton Luiz Figueiredo Moura da Silva: Graduado em História pela Unesp (2008), mestre também em História pela Unifeso (2016) e doutorando pelo Programa de Pós-Graduação em Medicina Preventiva da USP. Atualmente é bolsista Capes.

\section{Como citar este artigo(Howto cite thisarticle):}

SILVA, Ewerton Luiz Figueiredo Moura da. O Combate à doença do sono nas colônias portuguesas na África: medicina sob o signo do racismo e do darwinismo social (1901-1932). In REVISTA TRANSVERSOS. "Dossiê: Histórias e Culturas AfroBrasileiras e Indígenas - 10 anos da Lei 11.645/08". Rio de Janeiro, no. 13, MAI-AGO, 2018,pp.79-101. Disponível em: <http://www.e-publicacoes.uerj.br/index.php/ transversos >. ISSN 2179-7528.DOI:10.12957/transversos.2018.35648 